Bryn Mawr College

Scholarship, Research, and Creative Work at Bryn Mawr College

Sociology Faculty Research and Scholarship

Sociology

1991

\title{
The Politics of Class, Race, and Gender: Access to Higher Education in the United States, 1960-1986
}

David Karen

Bryn Mawr College, dkaren@brynmawr.edu

Let us know how access to this document benefits you.

Follow this and additional works at: http://repository.brynmawr.edu/soc_pubs

Part of the Sociology Commons

\section{Custom Citation}

Karen, David. "The Politics of Class, Race, and Gender: Access to Higher Education in the United States, 1960-1986." American Journal of Education 99, no. 2 (1991): 208-237.

This paper is posted at Scholarship, Research, and Creative Work at Bryn Mawr College. http://repository.brynmawr.edu/soc_pubs/1

For more information, please contact repository@brynmawr.edu. 


\title{
The Politics of Class, Race, and Gender: Access to Higher Education in the United States, 1960-1986
}

\author{
DAVID KAREN \\ Bryn Mawr College
}

This article, synthesizing the available (published and unpublished) evidence, describes patterns of inciusion of African-Americans, women, and working-class youth into the system of higher education from 1960 to 1986. Focusing not only on whether access has increased, but on whether these subordinate groups have gained access to elite institutions, this article examines the three groups in and across two periods $(1960-76 ; 1976-86)$ to highlight differential patterns of access and to suggest a plausible explanation involving political mobilization to account for the observed trends. Although the general expansion of the system of higher education since 1960 has led to reduced differentials in access between dominant and subordinate groups, women and blacks - who mobilized - were able to gain access even to elite institutions. Workingclass youth did not experience such gains. A key factor that mediates these benefits of political mobilization is the recognition of the group as an official category in the society's system of classification. L'sing a variety of data sources, this article shows that, during times of both mobilization and countermobilization, access to particular levels of the higher education hierarchy generally follows the hypothesized directions. Further research that focuses on the precise mechanisms by which political mobilization produces the observed results is called for.

\section{Introduction}

In this article, I present a distillation of the published (and some unpublished) evidence on the access of African-Americans, women, and working-class youth to higher education from 1960 to 1986 . In addition, I examine the available information on where, within the system of higher education, students from these groups have been located. Finally. I propose a tentative explanation - involving political

(C) 1991 by The University of Chicago. All rights reserved.

0195-6744/91/9902-0003\$01.00 
mobilization - for the sources of the patterns that 1 find in my data synthesis.

Research on access to higher education in the United States has been conducted, by and large, at the individual level of analysis. Researchers have traditionally been concerned with the probability of a given individual's attending college and with the relative effects of her or his background and ability on that likelihood (see, e.g., Alexander and Eckland 1974; Hearn 1984, in press; Thomas et al. 1979; Werts 1968). More refined analyses of who attends what kind of institution of higher education (see, e.g., Alexander and Eckland 1977; Karabel and Astin 1975; Hearn 1990, in press) and studies of the effect of specific loan or grant programs on a student's probability of college attendance (see, e.g., Leslie and Brinkman 1987; Manski and Wise 1983) also have used the individual as the unit of analysis. In looking at trends in access to higher education, analysts have relied on similar individual-leve! data collected at two (or more) points in time (see Alexander et al. 1987a, 1987b; Clowes et al. 1986; Peng 1977). While certainly critical to our deepening knowledge about the process of educational attainment at the individual level and very helpful for our assessment of various social policies, these analyses are less useful in assessing changes over time in the access of particular social aggregates to higher education. Specifically, these analyses omit the larger demographic patterns that essentially constitute the structure of opportunity for access to higher education and that constrain individual decision making about college entry.

To address this situation, I propose to analyze two related yet separate issues about access to higher education. First, I shall examine patterns of access to college from 1960 to 1986 by race, gender, and farnily background. Since women, blacks, and working-class youth have been relatively underrepresented in higher education, it is appropriate to assess their rates of enrollment during a period in which governmental attention to equality of opportunity has been strong. Further, it is only since 1960 that data collection has been reasonably systematic. ${ }^{1}$ Despite the many studies that have assessed the direct and/or indirect effects of being black, female, or from a lower socioeconomic group on probability of attending college, there does not exist a useful synthesis of the demographic evidence.

DAIID KAREX is an assistant professor of sociology at Bryn Mawr College. He is currently involved in research on the gatekeeping process at elite colleges. 
Second, since returns to higher education differ by the type of institution one attends ${ }^{2}$ (see Dougherty 1987; Karabel and McClelland 1987; Brint and Karabel 1989; Smart 1986; Useem and Karabel 1986), it is important to examine who attends what kinds of institutions. If equalizing opportunity is an important goal, then it would be critical to scrutinize the distribution of groups in the different sectors of higher education. For if subordinate groups were disproportionately found in those institutions that yielded the smallest returns, then the appearance of equality of opportunity (with respect simply to college access) would mask significant differences in the likely eventual career trajectories of these students. ${ }^{3}$ If students from subordinate groups were disproportionately concentrated in the lowest tier of the system, their relative position in the social structure would be maintaineddespite the sacrifices that they will have made to attend college and despite the real increase in educational mobility from generation to generation. Similarly, if they were relatively excluded from elite sectors of the higher education hierarchy, then the benefits that accrue from attendance at prestigious institutions-in terms of contacts, cultural refinement, and access to elite occupational sectors-would be less available to those from subordinate groups. In assessing equality of opportunity for access to higher education, one must take account as well of the likely destinations of subordinate groups within higher education.

To anticipate the tentative explanation that I shall offer below, I argue that subordinate groups that mobilized politically, namely, women and blacks, were able to increase their representation not only in higher education generally but even in those institutions that heightened one's probability of gaining access to elite occupational sectors. Workingclass students, who did not mobilize, were able to increase their access to college-primarily because of the absolute number of places that opened up-but were not able to gain access to the top colleges. A key mechanism leading to this outcome is that blacks and women have been recognized as official social categories by elite colleges in ways that working-class students have not. Between 1976 and the present, an era that I characterize as one of "countermobilization," black enrollments have declined, women's enrollments have continued to increase, and working-class enrollments have remained relatively constant. Ultimately. 1 argue that this pattern is largely consistent with the explanation that I develop with respect to the initial political mobilization.

The methodological basis for this argument is that I compare three groups in and across two periods $(1960-76 ; 1976-86)$ in an attempt to tease out the differences and commonalities in the patterns of access to higher education. Although the data used in this article do not 
address the precise mechanisms that led to the changes in access to different parts of the higher education system for women, workingclass, and African-American students, the comparative framework provides the necessary leverage to highlight differential patterns of access that suggest the important role played by political mobilization and countermobilization.

In the next two sections, I shall review the data on access to higher education for women, blacks, and working-class students from 196076 and 1976-86. In addition, I shall pay particular attention to where, within the higher educational system, these groups have been located. Finally, I will introduce the political mobilization perspective in detail, suggesting precisely how it illuminates the patterns that have been observed.

\section{Access to Higher Education, 1960-76}

\section{High School Graduation Rates}

Probably the most important factor in increasing black and workingclass representation in higher education-given a relatively constant rate of college attendance among high school graduates ${ }^{4}$ - has been the huge increase in high school graduation rates. Among those 2529 years old, the percentage of high school graduates in the population has increased from approximately 61 percent in 1960 to 83 percent in 1975. Black and white rates have become much closer. In 1960, 63.7 percent of whites and 38.6 percent of blacks had been graduated from high school; by 1975, however, the gap had narrowed to a 13percentage-point difference with a white rate of 84.4 percent and a black rate of 71 percent. ${ }^{5}$ With respect to working-class high school graduation rates, I have computed, on the basis of the 1973 Current Population Survey Supplement ("Occupational Changes in a Generation" [OCG]), educational attainment rates for those who were 2534 years old in 1963 and $1973 .{ }^{6}$ For sons of fathers who completed seven or fewer years of schooling. the percentage who at least had been graduated from high school increased from 53.9 to 58.2 percent for the two cohorts. Sons of fathers who had had at least some college attained this level of education at rates of 94.5 and 95.8 percent for these cohorts. During these years. then, we see that "class" differences in attaining high school graduation have been somewhat reduced.

Women's participation in higher education follows a different path from that of other subordinate groups because, growing up in the 
same families, they share the same social backgrounds as men. The specific nature of gender oppression, then, sets women apart as we attempt to understand their educational trajectories. As far back as data are available (1870), more women than men were graduated from high school in any given year. Perhaps the most extreme ratio was in 1900 , when the number of women being graduated was 50 percent higher than the number of men $(57,000$ to 38,000$)$. Although the male-female difference is not as extreme today, women's high school graduation rates continue to surpass men's (U.S. Department of Education $1987 b$, p. 83). Despite this long-term continuous high school graduation advantage, however, women's higher education enrollments did not surpass men's until 1979 (L.S. Department of Education, 1987b, p. 122).

\section{Enrollments in Higher Education}

Between 1960 and 1975, total enrollment in institutions of higher education in the Lnited States more than tripled, increasing from 3.6 million to 11.3 million students. ${ }^{7}$ In such a situation in which the number of places within the system of higher education expanded so massively, we would expect that groups that had previously been relatively poorly represented - for our focus, women, blacks, and workingclass youth-would increase their presence.

In the 1960-76 period, the number of women college students per 100 men went from 59 to 89 ( 37 to 47 percent; see table 1), signaling a massive relative increase in women's enrollments. Notwithstanding the structural growth of the system that permitted this change and the worldwide secular increase in women's participation in higher education (Ramirez and Boli 1987), women's changing labor force participation, rising divorce rates, and lower fertility must be seen as precipitants both of the growth of women's enrollments (see Walters 1986) and, as I will argue below, of the origins and further trajectory of the women's movement (see Klein 1984). As of 1985, women constituted 53 percent of first-time enrollments in higher education.

With respect to race, although the data are sketchy, ${ }^{8}$ it appears that blacks constituted 4.3 percent of total college enrollment in 1960 and 9.8 percent in 1975 (Gordon 1976). According to census data, it appears that the college-attending rate of 18-24-year-old blacks went from 7 percent in 1960 (cited in Astin 1982, p. 79) to 15.5 percent in 1970 to 22.6 percent in 1976 (L.S. Bureau of the Census 1988, pp. 8586; see tables 2-4), more than tripling in this 17 -year period. It is worth noting that from 1960 to 1970 to 1976 the ratio of the percentage 


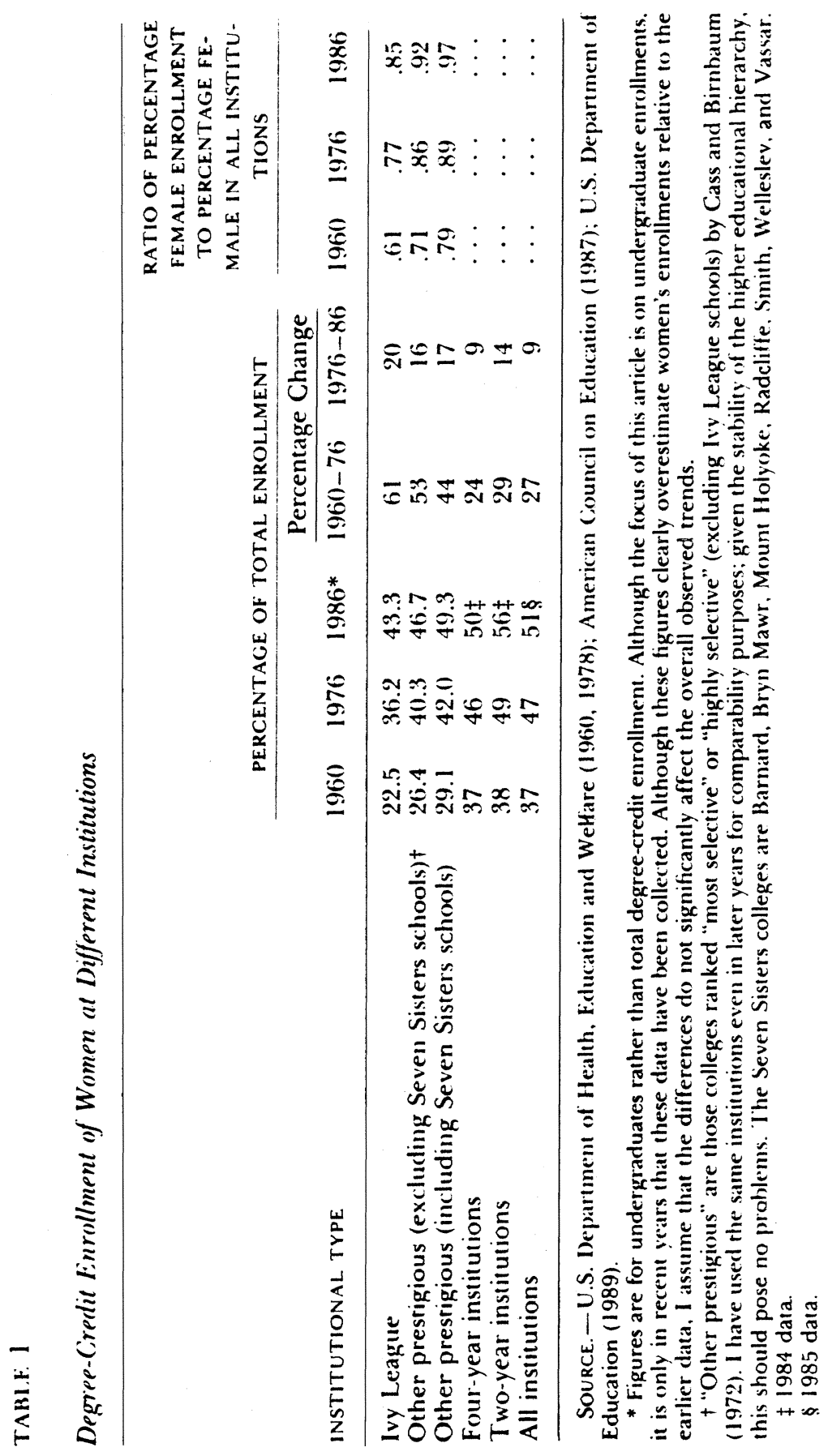


The Politics of Access to Higher Education

TABLE 2

Percentage of Blacks at Different Types of Institutions

\begin{tabular}{lccccc}
\hline Institutional Type & 1967 & 1970 & 1974 & 1976 & 1986 \\
\hline Ivy League & 2.3 & 5.1 & 6.7 & 6.3 & 5.8 \\
Other prestigious & 1.7 & 3.9 & 4.5 & 4.8 & 4.3 \\
\hline
\end{tabular}

SOLRCE. - Chronicle of Higher Education (1968); Levitan, Johnston, and Taggart (1975, p. 101); U.S. Department of Education (1989); U.S. Department of Health, Education and Welfare $(1974,1976)$.

of 18-24-year-old blacks enrolled in college to the percentage all 1824-year-olds enrolled in college went from .32 to .57 to .85 .

Finally, it is possible to infer from various data sources how college enrollment patterns changed for those in different socioeconomic circumstances. First, it appears from Featherman and Hauser's analysis of the 1973 OCG study (Featherman and Hauser 1978) that the effect of father's occupation on male college attendance is smallest for the youngest cohort in their sample (born between 1947 and 1951 and entering college between 1965 and 1969; those born between 1927 and 1941 evidence the highest dependence of college attendance on father's occupation).$^{9}$ Second, between the time of the Project TALENT study (1961) and the National Longitudinal Study of the High School Class of 1972, it appears that there was a slightly greater relative increase in high school graduates' college attendance from lower socioeconomic groups than from higher groups (see Peng 1977). Recognizing that high school graduation rates increased more at lower than at higher socioeconomic levels during this period, we see more clearly that the gap in college access has been reduced. ${ }^{10}$ Third, using data from Current Population Reports, Suter (1980, p. 22) presents data that suggest that, among people of college age, there was between 1960 and 1977 a slight diminution in the difference in the rates of college attendance between those from families with incomes under $\$ 10,000$ and those with incomes over $\$ 20,000$ (constant dollars). ${ }^{11}$ Overall, then, because of increases in rates of high school graduation and because top socioeconomic groups reached a ceiling in their rates of college entrance, it appears that class differentials in access to higher education have diminished. During a period in which the system of higher education massively expanded. all three subordinate groups, then, experienced relative increases in their college participation. 


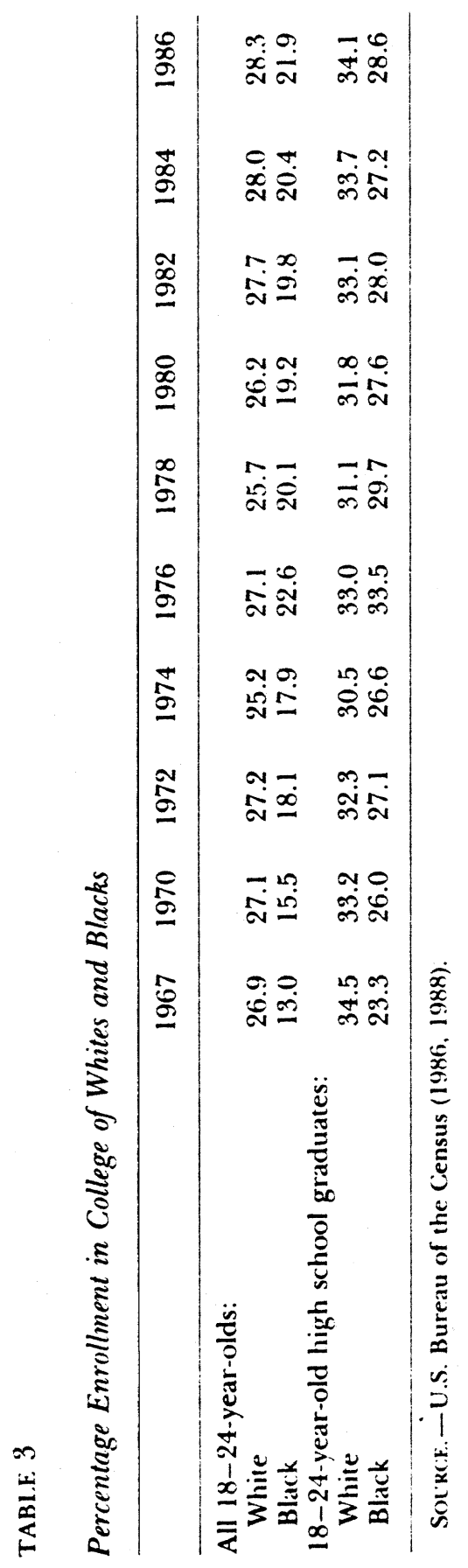


The Politics of Access to Higher Education

TABLE 4

Percentage of College Students

at Tuo-Year Colleges

\begin{tabular}{llll}
\hline & 1966 & 1976 & 1986 \\
\hline Black & 21.7 & 41.5 & 43.1 \\
White & 17.2 & 33.8 & 36.1 \\
\hline
\end{tabular}

SOLRCE. - U.S. Bureau of the Census (1969);

L.S. Department of Education (1988a, p. 170).

NoTE. - Data for 1966 reflect undergraduate enrollment: figures for 1976 and 1986 are for total enrollment.

\section{Enrollments in Higher Education by Sector}

To the extent, however, that where one goes to college is consequential for various stratification outcomes (see, e.g., Karabel and McClelland 1987; Reed and Miller 1970; Useem and Karabel 1986; Solmon 1975), it is important to examine subordinate groups' patterns of access to different levels of the higher educational hierarchy and to elite institutions in particular. For if we wish to examine whether subordinate groups' opportunities for social mobility in the society are increasing, then certainly we must scrutinize patterns of access to elite institutions that serve, in various ways. as transmission belts to high-status positions in the social structure. Martin Trow has argued, in fact, that "the advantages of elite institutions are so overwhelming that they create what is for them (but perhaps not for the rest of higher education or the larger society) a kind of 'virtuous circle' in which advantage begets advantage" (Trow 1984, p. 149). ${ }^{12}$ Though very suggestive, the data are, unfortunately, somewhat sketchy. ${ }^{13}$ Lsing a variety of sources, I shall review the information concerning women's, blacks', and workingclass access to different parts of the sistem of higher education during this time.

As noted above, women's enrollments in higher education increased tremendously between 1960 and 1976. It is interesting, however, that there were differences in rates of growth in different parts of the system. While women's share of total enrollment in all institutions increased from 37.1 to $4 \bar{i} .4$ percent, it increased from 35.6 to 48.9 percent in public two-year colleges and from 28.6 to 41.2 percent in private universities (L'S. Department of Health, Education and Welfare 
1961, 1978). Other data, reported in table 1, enable us to examine women's access to top-tier institutions between 1960 and 1976. Ivy League and "other prestigious" 14 institutions showed remarkable rates of growth in women's access in this period. with the odds of a woman's attending a top-flight school, given that she was attending college at all, increasing tremendously (see "Ratios" in table 1).

If we focus on high school graduates' college-attending behavior immediately after graduation, we also see women approaching the patterns of men in college entry. Using two panel studies-the 1961 TALENT study and the National Longitudinal Study of the Class of 1972-Peng (1977) shows that in this decade men's enrollment in four-year colleges declined from 37 to 30 percent while women's declined only from 29 to 28 percent. ${ }^{15}$ Rates of increase for two-year college enrollments were about the same for men and women. Women's representation in more prestigious institutions, then, increased relative to men's during this decade.

As noted above, there was a tremendous change in the representation of African-Americans in institutions of higher education in the period under discussion. Although data on where people go to college are incomplete, I shall attempt to show that blacks were able to make inroads even into the top institutions. Lising a number of different data sources, it appears that there were increases in black attendance at top institutions between the mid-1960s and mid-1970s. Two sources use the concept of "college rank" to indicate differences among postsecondary institutions, although the definitions used are somewhat different. To assess change over time, then, one must look at the ratio of black to white percentages at "high-rank" colleges within a given year (and a given definition) rather than examine changes over time in the percentages for each race. In 1966, according to the census bureau (1969), the percentage of blacks attending college at high-rank institutions was 8.5 , while that for whites was 23.4 , a ratio of .36 . In 1972, according to Bailey and Collins (1977). 11.8 percent of blacks attending college were at high-rank institutions, compared with 17.3 percent of whites, a ratio of .68. During this period, then, blacks seem to have become much more likely to be represented in prestigious colleges relative to whites than they had been before.

Data from institutions appear to corroborate this finding. although the earliest available data are for 1967 . As shown in table 2 . blacks made up 2.3 percent of Ivy League undergraduate enrollments in $1967,5.1$ percent in $1970,6.7$ percent in 1974 , and 6.3 percent in 1976. For "other prestigious" colleges, the figures were 1.7 percent in $1967,3.9$ in $1970,4.5$ in 1974, and 4.8 in 1976. The percentage of black college students in two-year colleges went from 22 percent 
in 1966 (undergraduates) to 42 percent in 1976; whites experienced a similar increase from 17 to 34 percent (see table 4 ). While growth at the bottom of the system was substantial, there is no gainsaying the significant increases in black enrollments at elite institutions during this period.

Finally, let us examine the college destinations of working-class / lower SES students. Although data are somewhat crude, it may even be the case that the relationship between being from a lower socioeconomic background and being located lower in the higher education hierarchy has become stronger. The reason for this "increasing stratification" hypothesis is that as more and more students complete high school, the college-eligible pool expands. Thus, students who a few years before would not have been able to go to college could, under new conditions, attend an institution of higher education. However, both because the "new" students are less selected than students had been in the past and because of the tremendous expansion of community colleges, students of working-class origin may have become increasingly likely to attend community colleges (Karabel 1972; Anderson, Bowman, and Tinto 1972).

Evidence that addresses this hypothesis comes from a number of different sources. First, from American Council on Education (ACE) data (see table 5), it appears that, between 1966 and 1976, students whose fathers had at least graduated from college became less likely to attendetwo-year colleges (relative to the representation of collegegraduate males among $40-49$-year-olds ${ }^{16}$ ), while those whose fathers had not graduated from high school became slightly more likely to attend such colleges (1.72 to 1.21 and .76 to .80 ; table 5). Relative to the percentage of 40-49-year-old men in the population who had at least graduated college, the percentage of students with highly educated fathers attending private universities declined ( 5.04 to 2.91 ; table 5 ), while, relative to 40-49-year-old men in the population who had not graduated high school, the percentage of students with non-high school graduate fathers attending private universities remained about the same (.32 to .31 ; table 5$)$. The odds of attending a private university compared with a two-year college among those whose fathers did not graduate high school (relative to the percentage of 40-49-year-old non-high school graduate males in the population) went from .42 in 1966 to .39 in 1976 (see table 5). The odds of attending a private university compared with a two-year college among those whose fathers were at least college graduates (relative to the percentage of 40-49year-old college-graduate males in the population) went from 2.9 in 1966 to 2.4 in 1976 (see table 5). It does not appear, then, that there is strong evidence that stratification by type of institution increased. 


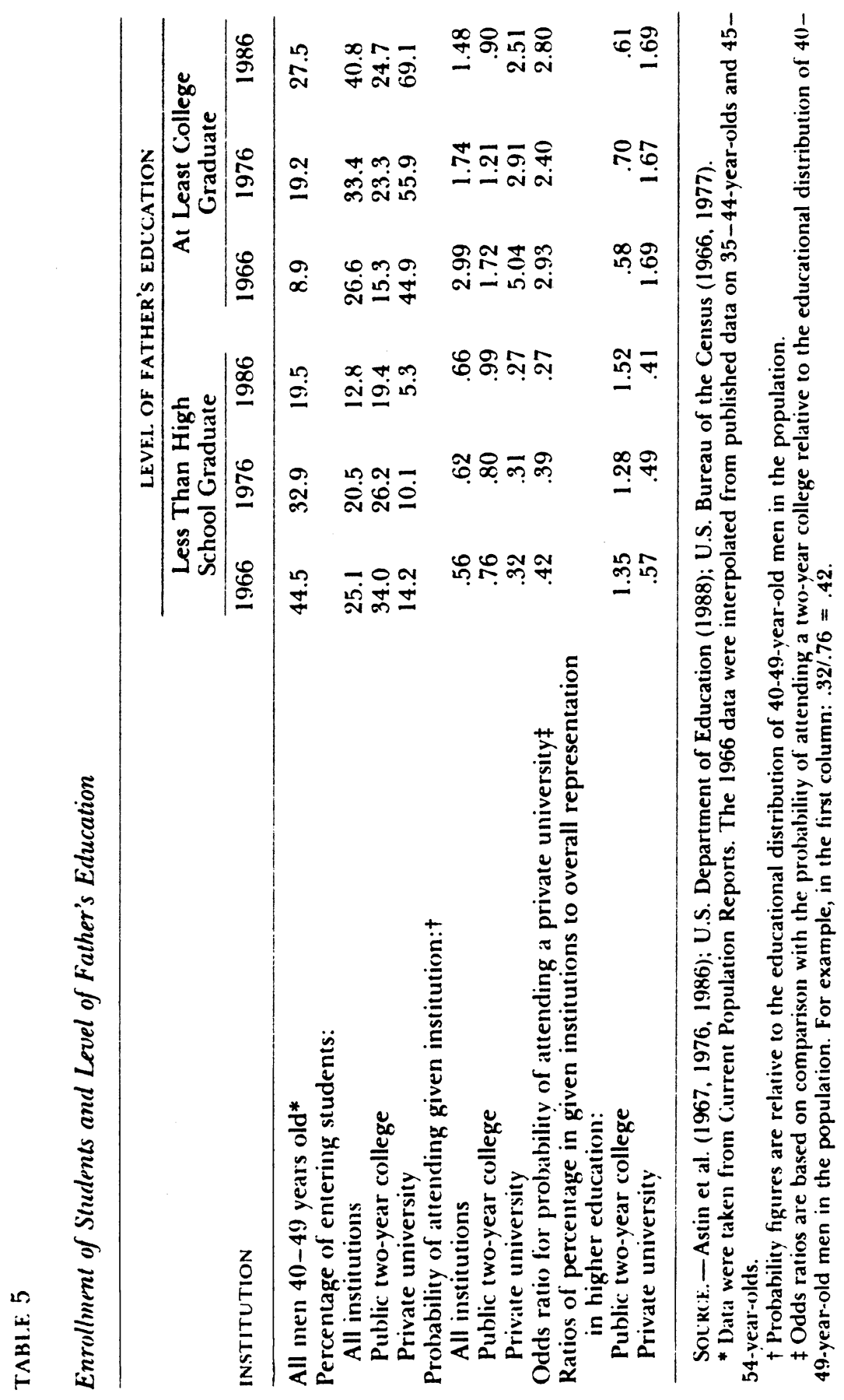


It seems, however, that students from lower educational backgrounds did not make inroads into top-tier institutions, as was evident with African-Americans and with women.

Using various ACE reports. McPherson (1978, p. 172) presents evidence on the relationship between type of institution and family income that is consistent with the "increasing stratification" hypothesis. At private universities, students from families with incomes less than half the median were 8 percent of all students in 1966 and 7 percent in 1975. Students from families with incomes more than twice the median increased their representation from 32 to 36 percent in 1966-75. At the other end of the higher educational spectrum, at public two-year colleges, the students from poorer families increased their representation from 17 to 20 percent in this period, while the students from well-off homes decreased their representation from 11 to 9 . These data based on income, then, support the notion that, as more working-class students have entered postsecondary institutions, they have become relatively more concentrated in the lowest tier.

Although the evidence for certain specific points could be more convincing, the main thrust of this survey of the distribution of three distinctly defined (but empirically overlapping) subordinate groups among different levels of the higher education hierarchy is that women and African-Americans have been able to move into top-tier institutions in ways that those from working-class groups have not. To the extent, then, that race and gender have become important categories that are relevant to the distribution of and mobilization for scarce resources - of which access to elite educational institutions is a prime example-and being of working-class or of low SES has not become an important category, our anticipated expianation of increasing access for all groups (as a result of structural change) but access to the top only for the mobilized groups becomes understandable.

\section{Access to Higher Education, 1976-86}

During the decade 1975-85, despite dire predictions about declines in enrollments, total enrollment in institutions of higher education increased by 9.5 percent to 12.25 million students, with most of that growth coming before 1980 . The question is where this growth came from and whether there were changes in subordinate groups' relative place within the system of higher education. I shall first discuss changes in blacks' enrollment in higher education, followed by a discussion of women's place in higher education, and concluding with a discussion of the effect of socioeconomic origins on recent enrollment patterns. 
During this decade, the gap between white and black high school graduation attainment declined: in 1985, 87 percent of white 25-29year-olds had been graduated from high school, and the corresponding figure for blacks was 81 percent. But with respect to college attendance, whether it is measured in terms of the percentage of high school graduates or of an age cohort, it appears that black participation in higher education reached a peak in 1976 and declined thereafter (although there appears to have been a recent upturn), as shown in table 3 (the percentage of all college students who were black was 9.4 percent in 1976, remained at 9.4 percent through 1978, then fell to 9.2 percent in 1980, 8.9 percent in 1982, 8.8 percent in 1984 , and 8.6 percent in 1986 [U.S. Department of Education 1988b]). Institutional data also confirm that blacks' share of higher educational enrollments reached its zenith in 1976 and began to decline after 1978. According to the recent National Research Council Report, A Common Destiny, "The rate of black high school graduates attending college rose from about 39 percent in 1973 to about 48 percent in 1977-when it was virtually equal to those [sic] of whites-and then fell continuously to about 38 percent through 1983 ... . In comparison, for 1973-1984, the college entry rate of whites rose almost continuously from about 48 percent to 57 percent" (Jaynes and Williams 1989, pp. 338-39).

With respect to where blacks were located within higher education, it is noteworthy, during this time of slackening overall enrollments and of increasing relative costs, that there were not disproportionate declines for blacks in elite institutions of higher education (see table 2 ). If blacks had not established themselves as an official category and attracted the attention of both government and higher education officials, it is likely that we would have witnessed a disproportionate decline at top-tier colleges. Below, I will explore working-class access (with no official category ${ }^{17}$ ) to examine this contention more closely.

Women, on the other hand, have continued their increase in enrollments. As noted above, because the class distribution of schoolaged females is the same as that of males and their cultural resources for use on standardized tests are largely similar, women are less susceptible than other subordinate groups to the negative effects of countermobilization. By 1985, women's enrollments made up 52.5 percent of total enrollment in higher education (U.S. Department of Education $1988 a$, p. 143). Even in individual-level analyses of high school seniors, researchers had found that the probability of females attending an institution of higher education had surpassed that for males (Alexander et al. 1987b). In addition, Clowes et al. (1986) found by comparing 1961, 1972, and 1982 high school graduates that, within comparable levels of SES and measured aptitude, women had become more likely 
than men to be enrolled in four-year colleges. In a more focused analysis, Alexander et al. (1987b) found, in a study of 1972 and 1980 high school graduates, that there were no differences in where men and women attended college once social background and academic resource variables were controlled (see also Eagle 1988). It is important to point out, however, that, with respect to the overall proportion of women in higher education (that is, without restricting our focus to recent high school graduates), their enrollments are disproportionately part-time and located in the community-college sector (American Council on Education 1987, p. 74). And, as table 1 makes clear, women's enrollments, as of 1986, approached but had not quite surpassed men's in the most elite sectors of higher education, despite their higher high school graduation rates. Hearn (in press) shows, using data from a national sample of 1980 high school seniors, that, if one holds social background, ability, and various high school factors constant, women attend less selective colleges than men. I suspect that women's overall enrollments will continue to remain higher than men's at the undergraduate level but that men's enrollments for professional and doctoral degrees will continue to be higher than women's (U.S. Department of Education 1988a, pp. 226-28).

With respect to working-class access, it appears that there has not been much change in recent years, although there is little information that allows comparisons between 1976 and the present. The most directly comparable data available are for 1972 and 1980 high school graduates' enrollment in college immediately following graduation. The data indicate that there was a slight change in the percentages continuing their education in the low-, medium-, and high-SES categories, with an overall decrease in the percentage difference between the top and bottom categories (U.S. Department of Education 1985, p. 224; see also Eagle and Carroll 1988). Alexander et al. (1987b) also conclude from a comparison of 1972 and 1980 high school graduates that there has been a very slight diminution between the top and bottom socioeconomic categories in the probability of attending college. ${ }^{18}$

With respect to class differentials in access to different kinds of colleges. Alexander et al. (1987a, p. 67) find that in both 1972 and 1980 high-SES college students are "about 1.26 times more likely than their low-SES counterparts to attend a four-year college." Clowes et al. (1986, p. 126) present a 1972-82 comparison of recent high school graduates that shows that, compared with students in the lowest socioeconomic quartile, male students in the top quartile were 2.1 times as likely to attend a four-year college in 1972 and 2.3 times as likely in 1982; female students in the top quartile were 2.2 and 2.6 times more likely than those in the bottom quartile to attend a four-year 
college in 1972 and 1982, respectively. Finally, using ACE data on entering students as reported in table $5, I$ would argue that, relative to the percentage of males $40-49$ years old in the population who did not graduate from high school, students from homes in which the father did not graduate from high school became more concentrated in public two-year institutions between 1976 and $1986(.80$ to .99$)$ and less likely to be found in private universities (.31 to .27). Among students whose fathers were college graduates, on the other hand, it seems that their representation in two-year colleges and in private universities declined (relative to the percentage of 40-49-year-old men in the population who are at least college graduates). To highlight the difference in where students from different backgrounds attend college, I have computed in table 5 a set of odds ratios that compares the probability of attending a private university to the probability of attending a two-year college (given the educational distribution of 40-49-year-old males). According to this measure, between 1976 and 1986, students from lower educational backgrounds became more concentrated in lower-tier colleges and students from college-graduate homes became more concentrated in private universities. Overall, although there is some evidence that working-class representation in higher education has remained relatively constant during the past decade, there is also reason to believe that there has been an increase in stratification in where these students go within the system of higher education-a situation that appears to be absent for the previously mobilized black population.

\section{Political Mobilization and Higher Education Enrollments}

As mentioned above, in this section, I focus on the role of political mobilization in effecting changes in higher education access for blacks, women, and working-class youth. I argue that political mobilization (and countermobilization) affects enrollments in higher education through its impact both on people's perceptions of the opportunity structure (and hence on their aspirations ${ }^{19}$ ) and on social policy directed at opening educational and occupational opportunity. The logic of the analysis stems from the comparative fact that, during this period, blacks and women have mobilized and have gained recognition as official social categories, whereas those from lower socioeconomic groupings have not. A key test of whether there are gains in access to valued resources as a result of political mobilization is whether the mobilized groups have been able to gain access to elite institutions of higher education. It is, after all, in these elite institutions that elaborate 
gatekeeping processes have been instituted (Karen 1985, 1990) and from these elite institutions that future elites are disproportionately selected (see Pierson 1969; Useem and Karabel 1986).

I see political mobilization as involving a collective effort on the part of individuals who are excluded from some critical resource (e.g., access to higher education) to change existing patterns of institutionalized behavior. This process may take many forms and occur at many levels and with many different kinds of participants. A key measure of the success of a given mobilization involves the realization of an official status in the society's system of classification (e.g., as codified in Title VI of the 1964 Civil Rights Act, which was supposed to enforce the desegregation of higher education institutions; see Trent and Braddock 1988). Bourdieu (1984, pp. 480-81) captures this idea when he states that "[a] group's presence or absence in the official classification depends on its capacity to get itself recognized, to get itself noticed and admitted, and so to win a place in the social order." Countermobilization involves the reassertion of power on the part of dominant groups to attempt to restore the status quo ante.

If political mobilization is to be seen as an important contextual element in particular kinds of increases in higher education attendance, then countermobilization on the part of entrenched groups should be expected to lead to decreases in enrollments. And, as with the mobilization for increased access, the effects of cauntermobilization should be seen in terms of both actual (e.g., specific social policies affecting financial aid availability) and perceived opportunity. It is not only that barriers to access will have been made higher but that people will have become less inclined to hurdle them.

The recognition of a subordinate group as an official social category, attained via classification struggles (see B surdieu 1984) in the larger society, is a key mediating factor in the effect of political mobilization on higher education enrollments. In fact, it seems that certain institutions, attendant both to black political mobilization on their campuses and the federal government's linkage of institutional subsidies to the implementation of affirmative action plans, eventually instituted extensive recruitment programs. During the early 1970s competition for "highly able" black students became intense, with prestigious colleges offering them all-expenses-paid campus visits (see Weinberg 1977, p. 34). Stadtman (1980, pp. 128-30) reports that recruitment efforts were much more likely to be found in upper-tier than in lower-tier institutions. Not only does the official categorization lead a specific institution of higher education to attend to the group, but it also continuously implores group members to define themselies as a group and to maintain a presence on campus. Because of their entrenchment 
in bureaucracies of elite institutions, these categories help preserve the gains of subordinate groups in elite institutions of higher education even if there are declines elsewhere in the system, as in the period of countermobilization.

In arguing that political mobilization has had effects on access to college, I do not mean to imply that it has been, in a given case, a precipitating or final cause. Other factors, no doubt, have been important as well. Specifically, it is important to view the government-both federal and state - as a key actor in mediating the effect of political mobilization on college access. Government officials, often for their own reasons, might wish to pay special attention to the claims of particular groups. ${ }^{20}$ Thus, higher educational expansion or retrenchment might have been on the agenda of a key education official when other groups mobilized for or against increased access. It is also the case, as Brint and Karabel (1989) point out, that the ideological context in the United States within which responses to mobilized groups are formulated is one that focuses more on providing the appearance of opportunity than on the reality of equality; compared with other advanced industrial societies, the United States spends relatively more money on education and relatively less on social welfare (Wilensky 1975 , p. 122). Access to higher education, then, might be particularly sensitive to the pulls and pushes of struggles for greater resources in the political arena.

If, as seems to be the case, the enrollment patterns of students of lower SES, women, and African-Americans in the 1960-76 period are consistent with the political mobilization argument, how, if at all, can we link the post-1976 patterns of declines in black enrollments to a countermobilization? ${ }^{21}$

First, we must ask, What is the nature of this countermobilization? It occurred on many levels and through various mechanisms. Perhaps at the most general level, the "fiscal crisis of the state" (see O'Connor 1973) can be seen as the primary context of the countermobilization. The source of the fiscal crisis was both economic and political. The economic problems stemmed from Lyndon B. Johnson's funding of both the Great Society and the Vietnam War without raising taxes, the major oil-based inflationary surge of the early 1970s. long-term international competitive decline, and a deepening profit squeeze that led to increased attempts by business to roll back wages (see Ferguson and Rogers 1986; Hodgson 1976). The political sources of the fiscal crisis were demands by business and political elites for increased military spending and decreased social spending and massive campaignsthrough foundations, think tanks, political action committees, and so on-for attacks on the "liberal press," for decreased attention to L.S. 
intervention abroad and poverty at home, and for increased attention to Soviet aggression (Ferguson and Rogers 1986, pp. 103-5). ${ }^{22}$ Were it not for the political context, the economic problems might have been dealt with through deficit spending (as with Johnson). We must understand, however, that the timing of fiscal (and other) crises is politically determined (see Alford 1975); in this context, deficit spending was not a plausible alternative "solution." Carter, who wished to pursue various liberal policies, was elected with a reputation for fiscal austerity and his orientation to "zero-based budgeting." Thus, the fiscal crisis of New York City that ultimately led to the imposition of tuition in the formerly free City University of New York and the national fiscal crisis indicated by Carter's attempts to reduce Federal spending must be seen in the context of financial and government elites having the power to impose a recognition and definition of crisis along with the corresponding constrained set of possible solutions. Reagan's ability to increase defense spending through deficit spending even in the context of a declared fiscal crisis underlines the specifically political nature of the crisis. ${ }^{23}$

More specifically, at the level of postsecondary education, the countermobilization led to federal funding declines in student aid and the Reagan administration's active neglect in the enforcement of affirmative action. With respect to declines in funding, of the six major Federal student financial aid programs (Pell Grants, Supplemental Educational Opportunity Grants, College Work-Study, National Direct Student Loans, State Student Incentive Grants, and Guaranteed Student Loans), only Guaranteed Student Loans, which, in constant dollars, reached its highest average amount in 1979-80, peaked after 1976-77 (U.S. Department of Education 1987a, p. 208). Since, during this time, the cost of higher education rose by a considerably larger amount than the rate of inflation, declining Federal aid meant that these funds were even less able to defray the costs of a college education. Finally, the entire tenor of the debate about education in the United States was focused on a "back to basics" program or a return to upholding standards - especially quantitative, measurable standards such as standardized tests. Evidently, our standards were falling and they needed to be raised; raising them would not only educate our young people but restore us to our proper place atop the world economy. ${ }^{24}$ Apparently, those behind the movement to restore standards saw a relationship between the declining relative place in the world economy and the recent democratization of our educational system. In short, during this period of countermobilization. many factors shaped the context within which one might expect that blacks' percentage share of higher education enrollments would have declined. 
With respect to women's enrollments, it seems that the women's movement may be likened to the GI Bill in the effect it had on a single group's higher education enrollments: it established a new threshold of education and of educational expectations for women in the context of a changed structure of opportunity. Since women always represented a greater percentage of high school graduates than men, in the absence of gender differences in access to educational and occupational opportunities, one might have expected women to have represented a greater percentage of college students than men. Once the women's movement began and federal legislation affected the opportunity structure, women's enrollments began to overtake men's.

Thus, the countermobilization did not affect disproportionately the enrollment of women and blacks in elite institutions of higher education, despite tuition increases that outpaced inflation (particularly among elite schools). With respect to overall enrollments, although black enrollments have declined, women's enrollments have not. ${ }^{25}$

\section{Discussion}

This survey of changes in enrollments in higher education for three subordinate groups has shown that there appears to be a relationship between political mobilization and access to valued resources. Groups that mobilized made inroads even into elite institutions, while the group that did not mobilize appeared to make no such gains. As noted throughout, there are numerous problems of data comparability in adducing evidence for this hypothesis. Nevertheless, through triangulation and comparison, the hypothesized trends do appear to have been confirmed. Further research on the precise mechanisms through which political mobilization exerts these effects is certainly necessary.

In a parallel effort to assess changes by race, class, and gender in access to higher education with the use of individual-level data, Alexander et al. (1987b, p. 181) found that SES differences in access to higher education were the most intractable. Perhaps because of political mobilization and groups' victories in the classification struggle, SES differences are smaller for blacks than for whites, and, within SES levels, blacks are generally more likely than whites to attend college. Of course, the huge differences in SES between blacks and whites points to the large distance that must still be traversed to attain equality of access to higher education.

Although the gains were certainly real, black and female increases in higher education followed a pattern that could probably be best described as a "co-optation response" of privileged groups to subordinate 
groups' demands. This pattern is one that allows for increases at the top but insures that the greatest absolute change is at the bottom of the system. Thus, access to higher education increases; access to elite institutions increases; but the lion's share of the change is concentrated in lowest-tier institutions. Despite the mobilization, then, blacks and women continue to be found disproportionately in the sector of higher education that yields the smallest socioeconomic returns (Dougherty 1987; Brint and Karabel 1989). Although the establishment of an official category protected blacks from a disproportionate decline in elite institutions, we might have found that there had been no falloff at all. I suspect that during the period of countermobilization many elite institutions continued their strong recruitment efforts, but, in the face of declining federal aid, the gutting of affirmative action enforcement, and the associated declining aspirations, they were less successful than they had been previously.

Just as groups on individual campuses have mobilized and have been successful in gaining greater admissions attention for alumni status, for race, and for test scores (see Karen, 1990), we also see that, at the national level, successful political mobilization appears to be associated with gains in access to higher education for those who mobilized. Although expanding the overall pie of higher education enrollments yields benefits to all subordinate groups, it seems that it is only when the threat from below is strong and pervasive that traditional selection criteria may be amended to allow for the admission of previously excluded groups. In this situation, one must look to the perceptions and interests of governmental and university elites for the keys-in both senses-to admission to the prestigious institutions.

\section{Notes}

This is a revised version of a paper presented at the annual meeting of the American Educational Research Association, San Francisco, March 31, 1989. This research was supported by a National Academy of Education Spencer Foundation Post-Doctoral Fellowship and a Bryn Mawr College Junior Leave. I would like to thank Paul DiMaggio, Kevin Dougherty, Jim Hearn, Jerome Karabel, Katherine McClelland, Aaron Pallas, David Riesman, and David Swartz for comments on previous drafts. Christopher Jencks offered particularly incisive and constructive comments.

1. Numerous problems of data comparability afflict the current endeavor. Over the years, the various organizations that have collected information about higher education en rollments have changed their definitions about evervthing from how a student is classified (resident degree-credit, total, undergraduate, extension, unclassified, etc.) to the kinds of institutions that are enumerated (four-year vs. two-year; universities, other four-year, two-year; doctoral, com- 
prehensive, general baccalaureate, etc.) to the way that race/ethnicity is categorized. In dealing with these problems I have attempted to give "best estimates" from the available data. In general, as will become obvious, I relied on multiple sources to examine the trends in enrollments; if the results agreed, I took this as confirmation of the observed trend. In some cases, I use data that are less than perfect (such as the enrollment data by institution for the 1960s and early 1970s, which I aggregate to "Ivy League" or "prestigious colleges") but seem to serve well as "reasonable estimates."

2. These returns may be of different kinds. The evidence suggests that different kinds of colleges may yield returns in the form of more years of education, different probabilities of a lucrative college major, and direct economic payoffs.

3. Following Parkin (1979), I am using the term "subordinate groups" to refer to those who are excluded from a set of resources over which there are struggles; in this article, women, racial/ethnic minorities, and those who are working-class/blue-collar/lower class/low socioeconomic status (SES) are the relevant groups. The lack of specificity for the working-class group is a function of the varied designations used in the collection of statistics and in the sociological literature. While gender and race/ethnicity have emerged as official categories, social class has not; advances in access to various resources follow this pattern of official group recognition that usually follows the group's constitution of itself, through political mobilization, as a social category to be reckoned with. For further discussion of the process of group formation and the emergence and effects of official recognition, see Przeworski (1977), Bourdieu (1984), and Karen (1990).

4. For our purposes, this is a not unreasonable assumption, as between 1967 and 1985, enrollment of 18-24-year-olds in college as a percentage of high school graduates varied by no more than four percentage points (see U.S. Department of Education 1988a, p. 174).

5. These data, collected in Current Population Reports, are reported in L'.S. Department of Education (1988c). It should be noted that these rates reflect educational attainment rather than the rates at which 17 -year-olds finish high school. Thus, those who complete high school through the armed forces, General Equivalency Diploma, etc. are included in these figures. That these rates are for 25-29-year-olds means that they underestimate the gains of 17year-olds during these years. Also, it should be noted that the 1960 figure for blacks is for blacks and other races; the 1975 figure is for blacks only.

6 . These figures are based on unpublished tabulations done by the Census Bureau. The figures are based on the reports of the 25-34- and 35-44-yearold cohorts. While there are certainly problems with this procedure (overreporting, underreporting, subsequent completions), it will underestimate the differences in attainment between the top and bottom of the class structure. Since we are interested in whether these differences decreased over time, we are thus conservatively estimating these changes over time.

7. These figures include enrollment in "outlying areas," such as ('anal Zone, Guam, etc. (American Council on Education 1987, p. 58).

8. It is noteworthy-in the context of our anticipated argument about political mobilization and official categories - that data on black enrollments in the early 1960s are difficult to obtain, as the census reports data only for "nonwhites." It was only after the civil rights movement had actually exerted effects that "black" emerged as an official social category and systematic data 
were collected. This difficulty in data collection, of course, is even more true for working-class/low-SES students, who are still not an official category in a similar sense.

9. In using the OCG study to make this claim it is important to note that overall-across all cohorts-Featherman and Hauser find no diminution in the effect of social origins on college attendance $(1978$, p. 25). In fact, Mare (1979), using the same data, argues that once the overall increases in educational attainment have been taken into account, there has actually been an increase in the dependence of college access on social origins. Mare argues that the relative stability of the (regression coefficient) effect of social origins on college access across cohorts that Featherman and Hauser find is a function of the overall increase in educational attainment that offsets the increase in dependence on social class. With respect to the present point, it is only the finding about the youngest cohort that is relevant; Mare's point emerges because he controls for the very phenomenon that we are exploring.

10. One might have expected that, being a more selected group, people in lower socioeconomic groups who were graduated from high school in 1961 would be more likely than the less selected later cohort to attend college. The fact that we see an increase, despite the change in the selectedness of the cohort, signals an even sharper diminution of class difference.

11. One might also note that, comparing the college enrollment rates of dependent family members aged 18-24 between 1967 and 1976, we see that the percentage enrolling in college from families earning less than $\$ 5,000$ (1967 dollars) went from 20 to 22.4 percent, while those in the $\$ 15,000$-andover category went from 68.3 to 58.2 percent (U.S. Bureau of the Census 1978).

12. Hearn (in press) summarizes the evidence on the various effects of college quality on students' attainments with respect to further education, occupational status, income, and career trajectory.

13. Once again, one might argue that in a society in which access to higher education is seen as democratic, distinctions among institutions of higher education rarely get official recognition.

14. For a definition, see table 1 . As is evident, I have explicitly differentiated Ivy League and "other prestigious" institutions from Seven Sisters institutions. Rather than representing any assumption of gender-based hierarchy among these institutions, I separate them because of the stratification consequences of attendance at the different institutions.

15. One might ask how there could be declines in enrollments during a decade in which higher education massively expanded. The reason is that high school graduation rates also increased. If we were looking at the percentage of an age cohort that attended college we would be looking at increases. Once we restrict our examination to high school graduates, we are necessarily taking into account the selectedness of the group. In 1961, with less of the age cohort's being graduated from high school, the graduates were more selected, more elite, and hence more likely to attend a postsecondary institution.

16. Following a suggestion of Christopher Jencks, I have used 40-49-yearold males as a baseline against which to measure changes in the educational distribution of college students' fathers. Although this ignores differential fertility, the bias should not change much over time.

17. Anonymous reviewers pointed out that working-class students did represent an official category in the sense that "low-income" students were potentially 
recipients of federal financial aid monies. Although this is true, the comparison with African-Americans is noteworthy. It seems that there were two key differences between the "low-income" category and the "black" category: first, the latter category became entrenched in institutions of higher education themselves, thanks, in part, to federal incentives; and second, the latter was a political category that could be said to have been "asserted," whereas the former could be said to have been "assigned" administratively. (Thanks to James Ito-Adler for this distinction.)

18. The comparisons here are between 1972, 1980, and/or 1982. Since subordinate-group representation in higher education seems to have peaked in 1976, it is possible that the evidence of diminution of class differentials in access actually masks a post-1976 period of decline. It could be that workingclass access increased from 1972 to 1976 and has been falling since then. Relative to 1972 , however, I observe an increase.

19. For elaboration, see Bourdieu and Passeron (1977), who refer to the "internalization of objective probabilities" as the process by which changes in the opportunity structure are converted into changed aspirations. Bourdieu (1977, pp. 495-96) attacks studies that show a strong effect of aspirations on subsequent outcomes because, given the kinds of adjustments to reality that people make, it is not surprising that "they have hoped for nothing that they have not obtained and obtained nothing that they have not hoped for." In the present context, the idea is that, if there is a significant positive response to a mobilization for access to greater resources in the context of a group asserting itself as a social classification, then the group's set of aspirations will change. With respect to higher education, a "significant" response is one that establishes a new threshold for a group's probability of access; this would lead to the change in aspirations (see Bourdieu and Passeron 1977, pp. 225-27). Both the change in the objective structure of opportunity and the struggle over classification (see Bourdieu 1984) independently contribute to the change in aspirations; it is in combination, however, that the changes are most consequential. According to A Common Destiny (Jaynes and Williams 1989, p. 343 ), there is some evidence that after an earlier period of relative equality in aspirations (if not higher aspirations for blacks), since 1984, there has been "a tendency for the collegiate aspirations of blacks to lag behind those of whites."

20. Piven and Cloward's (1972) argument that the Democratic party sponsored community-based social programs in the early 1960 s so as to avoid Republicancontrolled city and state governments is a very good example of how the claims of mobilized groups and the interests of government officials might coincide to produce a specific outcome. Block (1977) and others (e.g., Skocpol 1981) have made the general point that state managers often act in their own interests in pursuing specific policy options. Karabel (1983) and Dougherty (1988) have usefully applied and developed this perspective in the arena of educational decision making.

21. Recent data releases (Wilson and Carter 1988; U.S. Department of Education 1988b) show that black enrollments have decreased significantly during the past decade but that Asian-American and Hispanic enrollments have increased. There are a number of factors specific to these groups that must be accounted for to explain this divergence from the general hypothesis. First, it is likely that the 18-24-year-old population among Asian-Americans and Hispanics has increased during the past decade because of increased 


\section{The Politics of Access to Higher Education}

immigration and because of these groups' age structure, with younger family members disproportionately represented. In this case, even if the percentage of 18-24-year-olds attending college remained constant during this decade, there would be an increase in their percentage share of higher education enrollments. Second, with respect to Asian-American enrollments, it is likely that a large percentage of their increase can be seen in the context of intergenerational transmission of privilege. Although Asian-Americans continue to be disadvantaged relative to whites with respect to elite college admission (see Karen 1985) and while there is a significant percentage that is workingclass, most Asian-American college students are, very likely, from professional or petty-bourgeois/entrepreneurial families. To the extent that this is the case, they have been able to increase their percentage share of higher education enrollments through traditional means of success, i.e., high test scores. Third, Asian-American political mobilization has increased recently. Fourth, with respect to Hispanic enrollments, I would also invoke the political mobilization hypothesis to explain their relative increase, although the population increase, most likely, explains the largest part of the increase. Since Hispanics are concentrated in just a few states and represent significant electoral blocs in those states, one might argue that it is only in the last decade that they are reaping the fruits of political mobilization. To underline this point, I should note that, in 1984, 71 percent of all Hispanic college students came from only four states: California, Florida, New York, and Texas (L'S. Department of Education $1987 b$, p. 154). The particular means by which Hispanics have been able to establish a political presence has been through their high concentration in a small number of states. In short, increases in the percentages of Hispanicand Asian-American enrollments maybe explainedin waysconsistent with the overall argument of this paper.

22. For an excellent account of the New Right's organization and mobilization, see Cranford (1980).

23. This discussion does not deny that there were serious political repercussions from failing to deal successfully with the stagflation that engulfed the economy. (Thanks to Christopher Jencks for highlighting this point.)

24. This pattern - of concern about standards and greater reliance on standardized tests - is precisely the one that we witnessed in the late 1950 s and early 1960s when the Soviet Lnion launched Sputnik and was apparently challenging our hegemon!.

25. To the extent that women, like men, may be located anywhere in the class structure, the background resources-cultural, economic, social-that they have available for college are not necessarily different from those available to men (although historically, of course. strategies of social mobility and reproduction have been different). Once the women's movement broke the historical links between gender and college access and lessened those between gender and occupational attainment more generally, countermobilization by conservative groups could not directly affect women's enrollment. If, however. women did not have access to those resources, their enrollments would no doubt have fallen off as well. The obvious comparison group is blacks. Whites and blacks differ greatly in their social origins and. thus. in their background resources; ultimately, these differences manifest themselies in differences in standardized test scores. For women to increase their access to higher education. administrative decisions to apply the same meritocratic criteria that had been applied to men would be. 10 a large extent. sufficient. For increases in black 
access, however, political mobilization had to attack traditional exclusionary criteria such as standardized tests. Thus, during a period of countermobilization, when traditional selection criteria are reasserted, blacks would be affected much more than would women.

\section{References}

Alexander, Karl L., and Bruce K. Eckland. "Sex Differences in the Educational Attainment Process." American Sociological Revieu' 29 (1974): 565-75.

Alexander, Karl L., and Bruce K. Eckland. "High School Context and College Selectivity." Social Forces 56 (1977): 166-88.

Alexander, Karl L., Scott Holupka, and Aaron M. Pallas. "Social Background and Academic Determinants of Two-Year versus Four-Year College Attendance: Evidence from Two Cohorts a Decade Apart." American Journal of Education 96 (1987): 56-80. (a)

Alexander, Karl L., Aaron M. Pallas, and Scott Holupka. "Consistency and Change in Educational Stratification: Recent Trends in Regarding Social Background and College Access." In Research in Social Stratification and Mobility, vol. 6, edited by Robert V. Robinson. Greenwich, Conn.: JAI, 1987. (b)

Alford, Robert. Health Care Politics. Chicago: University of Chicago Press, 1975.

American Council on Education. 1986-87 Fact Book on Higher Education. New York: Macmillan, 1987.

Anderson, C. Arnold, Mary Jean Bowman, and Vincent Tinto. Where Colleges Are and Who Attends. New York: McGraw-Hill, 1972.

Astin, Alexander W. Minorities in American Higher Education: Recent Trends, Current Prospects, and Recommendations. San Francisco: Jossey-Bass, 1982.

Astin, Alexander W., Kenneth C. Green, William S. Korn, and Marilynn Schalit. The American Freshman: National Norms for Fall 1986. Higher Education Research Institution, Graduate School of Education, University of California, Los Angeles. Prepared by the staff of the Cooperative Institutional Research Institute. Washington, D.C.: American Council on Education, 1986.

Astin, Alexander W., Margo R. King, and Gerald T. Richardson. The American Freshman: National Norms for Fall 1976. Laboratory for Research in Higher Education, Graduate School of Education, University of California, Los Angeles. Prepared by the staff of the Cooperative Institutional Research Program. Washington, D.C.: American Council on Education, 1976.

Astin, Alexander, W., Robert J. Panos, and John A. Criager. National Norms for Entering College Freshmen (American Council on Education Research Reports, vol. 2, no. 1). Washington, D.C.: American Council on Education, 1967.

Bailey, J. P., Jr., and E. F. Collins. "Entry into Postsecondary Education." Paper presented at the annual meeting of the American Educational Research Association, New York, April 1977.

Block, Fred. "The Ruling Class Does Not Rule: Notes towards a Marxist Theory of the State." Socialist Revolution 6 (1977): 6-28.

Bourdieu, Pierre. "Cultural Reproduction and Social Reproduction." In Power and Ideology in Education, edited by Jerome Karabel and A. H. Halsey. New York: Oxford Lniversity Press, 1977. 
Bourdieu, Pierre. Distinction: A Social Critique of the Judgement of Taste. Cambridge, Mass.: Harvard University Press, 1984.

Bourdieu, Pierre, and Jean-Claude Passeron. Reproduction: In Education, Society, and Culture. Beverly Hills, Calif.: Sage, 1977.

Brint, Steven, and Jerome Karabel. The Diverted Dream: Community Colleges and the Promise of Educational Opportunity in America, 1900-1985. New York: Oxford University Press, 1989.

Cass, James, and Max Birnbaum. Comparative Guide to American Colleges. New York: Harper \& Row, 1972.

Chronicle of Higher Education. "White, Negro Undergraduates at Colleges Enrolling $\mathbf{5 0 0}$ or More, as Compiled from Reports to U.S. Office for Civil Rights." Chronicle of Higher Education (April 22, 1968), pp. 3-4.

Clowes, Darrel A., Dennis E. Hinkle, and John C. Smart. "Enrollment Patterns in Postsecondary Education, 1961-1982." Journal of Higher Education 57 (1986): 121-33.

Crawford, Alan. Thunder on the Right: The "New Right" and the Politics of Resentment. New York: Pantheon, 1980.

Dougherty, Kevin. "The Effects of Community Colleges: Aid or Hindrance to Socioeconomic Attainment?" Sociology of Education 60 (1987): 86-103.

Dougherty, Kevin. "Educational Policy-making and the Relative Autonomy of the State: The Case of Occupational Education in the Community College." Sociological Forum 3 (1988): 400-432.

Eagle, Eva. "High School and Beyond: Educational Experiences of the 1980 Senior Class." Unpublished tabulations, U.S. Department of Education, Longitudinal Studies Branch, Educational Outcomes Division, Office for Educational Research and Improvement, 1988.

Eagle, Eva, and C. Dennis Carroll. "Postsecondary Enrollment, Persistence, and Attainment for 1972, 1980, and 1982 High School Graduates." Paper prepared for U.S. Department of Education, Office of Educational Research and Improvement. Washington, D.C.: Government Printing Office, 1988.

Featherman, David, and Robert M. Hauser. Opportunity and Change. New York: Academic Press, 1978.

Ferguson, Thomas, and Joel Rogers. Right Turn: The Decline of the Democrats and the Future of American Politics. New York: Hill \& Wang, 1986.

Gorden, Milton A. "An Analysis of Enrollment Data for Black Students in Institutions of Higher Education from 1940-1972." Journal of Negro Education 45 (1976): 117-121.

Hearn, James C. "The Relative Roles of Academic, Ascribed, and Socioeconomic Characteristics in College Destinations." Sociology of Education 57 (1984): 22-30.

Hearn, James C. "Pathways to Attendance at Elite Colleges." In The High Status Track: Studies of Elite Schools and Stratification, edited by Paul W. Kingston and Lionel S. Lewis. Albany: State Lniversity of New York Press, 1990.

Hearn, James C. "Academic and Non-academic Influences on the College Destinations of 1980 High School Graduates." Sociology of Education, in press." Hodgson, Godfrey. America in Our Time. New York: Doubleday, 1976.

Jaynes, Gerald D., and Robin Williams, Jr. A Common Destiny: Blacks and American Society. W'ashington, D.C.: National Academy, 1989.

Karabel, Jerome. "Community Colleges and Social Stratification." Hartard Educational Revieu' 42 (1972): 521-62.

Karabel, Jerome. "The Politics of Structural Change in American Higher 
Education: The Case of Open Admissions at the City Lniversity of New York." In The Compleat University: Break from Tradition in Three Countries, edited by Harry Hermanns, Ulrich Teichler, and Henry Wasser. Cambridge, Mass.: Schenkman, 1983.

Karabel, Jerome, and Alexander W. Astin. "Social Class, Academic Ability, and College 'Quality." Social Forces 53 (1975): 381-98.

Karabel, Jerome, and Katherine E. McClelland. "Occupational Advantage and the Impact of College Rank on Labor Market Outcomes." Sociological Inquiry 57 (1987): 323-47.

Karen, David. "Who Gets into Harvard? Selection and Exclusion at an Elite College." Ph.D. Dissertation, Harvard University, Department of Sociology 1985.

Karen, David. "Toward a Political-Organizational Model of Gatekeeping: The Case of Elite Colleges." Sociology of Education 63 (1990): 227-40.

Klein, Ethel. Gender Politics. Cambridge, Mass.: Harvard University Press, 1984.

Leslie, L. L., and P. T. Brinkman. "Student Price Response in Higher Education: The Student Demand Studies." Journal of Higher Education 58 (1987): 181204.

Levitan, Sar A., William B. Johnston, and Robert Taggart. Still a Dream: The Changing Status of Blacks since 1960. Cambridge, Mass.: Harvard University Press, 1975.

Manski, Charles F., and David A. Wise. College Choice in America. Cambridge, Mass.: Harvard University Press, 1983.

Mare, Robert D. "Social Background Composition and Educational Grow'th." Demography 16 (1979): 55-71.

McPherson, Michael S. "The Demand for Higher Education." In Public Policy and Private Higher Education, edited by D. W. Breneman and C. E. Finn. Washington, D.C.: Brookings, 1978.

O'Connor, James. The Fiscal Crisis of the State. New York: St. Martin's, 1973.

Parkin, Frank. Marxism and Class Theory: A Bourgeois Critique. New York: Columbia University Press, 1979.

Peng, S. S. "Trends in the Entry to Higher Education: 1961-1972." Educational Researcher (1977), pp. 15-19.

Pierson, George W. The Education of American Leaders. New York: Praeger, 1969.

Piven, Frances Fox, and Richard Cloward. Regulating the Poor. New York: Vintage, 1972.

Przeworski, Adam. "Proletariat into a Class: The Process of Class Formation from Karl Kautsky's The Class Struggle to Recent Controversies." Politics and Society 7 (1977): 343-401.

Ramirez, Francisco O., and John Boli. "Global Patterns of Educational Institutionalization." In Institutional Structure: Constituting the State, Societ, and the Individual, edited by George M. Thomas, John W. Meyer, Francisco O. Ramirez, and John Boli. Beverly Hills. Calif.: Sage, 1987.

Reed, Ritchie H., and Herman P. Miller. "Some Determinants of the Variation in Earnings for College Men." Journal of Human Resources 5 (1970): 17790.

Skocpol, Theda. "Political Response to Capitalist Crisis: Neo-Marxist Theories of the State and the Case of the New Deal." Politics and Societ 10 (1981): $155-201$. 
Smart, John C. "College Effects on Occupational Status Attainment." Research in Higher Education 24 (1986): 73-95.

Solmon, Lewis C. "The Definition of College Quality and Its Impact on Earnings." Explorations in Economic Research 2 (1975): 537-87.

Stadtman, Verne A. Academic Adaptations: Higher Education Prepares for the 1980s and 1990s. San Francisco: Jossey-Bass, 1980.

Suter, Larry E. "Elementary and Secondary School Progression, High School Graduation, and College Entrance of the American Population: 1950 to 1978." In Research in Sociology of Education and Socialization, vol. 1, edited by Alan C. Kerckhoff. Greenwich, Conn.: JAI, 1980.

Thomas, Gail E., Karl L. Alexander, and Bruce K. Eckland. "Access to Higher Education: The Importance of Race, Sex, Social Class and Academic Credentials." School Review 87 (1979): 133-56.

Trent, William T., and Jomills H. Braddock III. "Trends in Black Enrollment and Degree Attainment." In Desegregating America's Colleges and Universities: Title VI Regulation of Higher Education, edited by John B. Williams III. New York: Teachers College Press, 1988.

Trow, Martin. "The Analysis of Status." In Perspectives on Higher Education: Eight Disciplinary and Comparative Views, edited by B. R. Clark. Berkeley and Los Angeles: University of California Press, 1984.

U.S. Bureau of the Census. "Educational Attainment: March 1966 and March 1965." Current Population Reports, ser. P-20, no. 158. Washington, D.C.: Government Printing Office, 1966.

U.S. Bureau of the Census. "Characteristics of Students and Their Colleges: October 1966." Current Population Reports, ser. P-20, no. 183. Washington, D.C.: Government Printing Office, 1969.

U.S. Bureau of the Census. "Educational Attainment in the United States: March 1977 and 1976." Current Population Reports, ser. P-20, no. 314. Washington, D.C.: Government Printing Office, 1977.

U.S. Bureau of the Census. "School Enrollment: Social and Economic Characteristics of Students: October 1976." Current Population Reports, ser. P-20, no. 319. Washington, D.C.: Government Printing Office, 1978.

U.S. Bureau of the Census. "School Enrollment - Social and Economic Characteristics of Students: October 1985 (Advance Report)." Current Population Reports, ser. P-20, no. 404. Washington, D.C.: Government Printing Office, 1986.

U.S. Bureau of the Census. "School Enrollment - Social and Economic Characteristics of Students: October 1986." Current Population Reports, ser. P-20, no. 429. Washington, D.C.: Government Printing Office, 1988.

U.S. Department of Education. The Condition of Education: Statistical Report, 1985 Edition. Office of Education Research and Improvement, National Center for Education Statistics. Washington, D.C.: Government Printing Office, 1985.

U.S. Department of Education. The Condition of Education: Statistical Report, 1987 Edition. Office of Educational Research and Improvement. Center for Education Statistics. Washington, D.C.: Government Printing Office, 1987. (a)

U.S. Department of Education. Digest of Education Statistics, 1987. Office of Educational Research and Improvement, National Center for Education Statistics. Washington, D.C.: Government Printing Office, 1987. (b)

U.S. Department of Education. Digest of Education Statistics, 1988. Office of 
Educational Research and Improvement. National Center for Education Statistics. W'ashington, D.C.: Government Printing Office, 1988. (a)

U.S. Department of Education. "Trends in Minority Enrollment in Higher Education, Fall 1976-Fall 1986," report prepared for Office of Educational Research and Improvement, Center for Education Statistics, Postsecondary Education Statistics Division, Washington, D.C., 1988. (b)

C.S. Department of Education. Youth Indicators 1988: Trends in the Well-Being of American Youth, Office of Educational Research and Improvement. Washington, D.C.: Government Printing Office, 1988. (c)

U.S. Department of Education. "1986 Postsecondary Education Data Survey." Unpublished tabulations, 1989.

U.S. Department of Health, Education and Welfare. Opening (Fall) Enrollment in Higher Education, 1960: Institutional Data. Office of Education, Circular no. 637. Washington, D.C.: Government Printing Office, 1960.

L.S. Department of Health, Education and Welfare. Opening (Fall) Enrollment in Higher Education, 1960: Analytic Report. Office of Education. Washington, D.C.: Government Printing Office, 1961.

U.S. Department of Health, Education and Welfare. Racial and Ethnic Enrollments in Institutions of Higher Education. Office of Civil Rights. Washington, D.C.: Government Printing Office, 1974.

U.S. Department of Health, Education and Welfare. Racial and Ethnic Enrollments in Institutions of Higher Education. Office of Civil Rights. Washington, D.C.: Government Printing Office, 1976.

U.S. Department of Health, Education and Welfare. Fall Enrollment in Higher Education 1976, Final Report. Education Division, National Center for Education Statistics. Washington, D.C.: Government Printing Office, 1978.

Useem, Michael, and Jerome Karabel. "Pathways to Top Corporate Management." American Sociological Review 51 (1986): 184-200.

Walters, Pamela B. "Sex and Institutional Differences in Labor Market Effects on the Expansion of Higher Education, 1952 to 1980." Sociology of Education 59 (1986): 199-211.

Weinberg, Meyer. A Chance to Learn: A History of Race and Education in the United States. Cambridge: Cambridge University Press, 1977.

Werts, Charles E. "A Comparison of Male vs. Female College Attendance Probabilities." Sociology of Education 58 (1968): 191-200.

Wilensky, Harold. The Welfare State and Equality. Berkeley: Lniversity of California Press, 1975.

Wilson, Reginald, and Deborah J. Carter. Minorities in Higher Education: Seventh Annual Status Report, 1988. Washington, D.C.: American Council on Education, 1988. 